\title{
De la historia del pensamiento y de sus principios. Aproximación a M. Foucault1
}

\section{On the History of Thought and its Principles. Approach to Michel Foucault}

\author{
Marco DíAz MARsá / Jorge DÁvila Rojas
}

(Universidad Complutense de Madrid, España / Universidad de los Andes, Mérida, Venezuela)

Recibido: $26 / 11 / 2013$

Aceptado: 27/02/2014

En memoria de Quintín

\section{Resumen}

Este estudio se define y articula a partir de la pregunta por el significado, sentido y estructura de la noción de "historia del pensamiento", tal como ésta emerge y actúa desde los últimos pronunciamientos e intervenciones de Foucault, de un modo singularmente claro y revelador a partir de la primera versión del Prefacio a la "Historia de la sexualidad" (1984), texto del que nos ocupamos con atención prioritaria a lo largo de este trabajo.

Palabras clave: Problematización, actualidad, historia, crítica, ontología, filosofía, política, principio.

\begin{abstract}
This study is defined and articulated on grounds of the question about the meaning, sense and structure of the notion of "history of thought" as it rises and functions from Foucault's last declarations and interventions, in a particularly clear and illuminating way after the first version of the Préface à l' "Histoire de la sexualité” (1984), which we will mindfully approach along this work.
\end{abstract}

\footnotetext{
${ }^{1}$ Este trabajo ha sido realizado en el marco del proyecto de investigación Naturaleza humana y comunidad II: H. Arendt, K. Polanyi y M. Foucault. Tres recepciones de la antropología política kantiana en el siglo XX (ref. FFI2009-12402), financiado por el Ministerio de Educación de España.
} 
Keywords: Problématisation, actuality, history, critique, ontology, philosophy, politics, principle.

\section{Historia del pensamiento: ¿cómo se relaciona el pensamiento con la historia?}

Tiene razón Deleuze al afirmar que el asunto que obsesiona de la manera más íntima el trabajo de Foucault no es el problema del saber, tampoco lo que el de Poitiers determina como ética, ni siquiera lo que hace comparecer en sus textos más conocidos como poder. Y es que aquello que Foucault define como el objeto esencial de su investigación, el blanco de su preocupación más general, es más bien el pensar $^{2}$, pero un pensar que sólo se ejerce como experiencia de un saber, siendo además un poder y un deber. Así, Deleuze podrá recordarnos la importancia sagital de la cuestión del pensamiento en Foucault: «"¿qué significa pensar? ¿A qué llamamos pensar?" la pregunta lanzada por Heidegger, retomada por Foucault, la flecha por excelencia» ${ }^{3}$, aquella que ha de afectar al presente en su mismo corazón.

Tal cuestión -la del pensar- confiere a la filosofía foucaultiana su sello inconfundible de modernidad crítica. Y es que sólo bajo la condición de un pensar moderno -la propia de una finitud primera aunque no fundamental y, por ende, paradójica4- puede emerger una efectiva problematización del pensamiento en sus límites de derecho, puede el pensar ser interrogado, en su forma de iure, a partir de algo que no es en absoluto pensar, que resiste al pensar y que viene a poner en cuestión al pensar en su pretendida inmediatez y luminosidad pura. Puede llamarse a ese algo, índice de la finitud del pensamiento o de la quiebra de la representación infinita $^{5}$, ser. Ahora bien, ser se abre en Foucault como saber, ser es también poder, ser, finalmente, es moral: saber, poder y moral son los tres ejes de la ontología foucaultiana 6 y la «triple raíz de una problematización del pensamiento»7. "Problematización" es pues ahora la palabra más señalada, algo distinto de una negación o de una disolución del pensamiento a partir de algo más verdadero y pro-

\footnotetext{
2 Ello se muestra con la claridad de lo postrero en los artículos, entrevistas y cursos que rodean la publicación del segundo y tercer volumen de Histoire de la sexualité, donde la noción de "problematización" se define como lo «esencial» y lo que otorga su «forma común» a las investigaciones foucaultianas , Cfr. "Le souci de la vérité" en Dits et écrits. 1954-1988, IV (4 vol.) (en adelante DE), Paris, Gallimard, 1994, p. 669.

3 Deleuze, G., Foucault, Barcelona, Paidós, 2007, p. 151.

4 Cfr. Díaz Marsá, M. "Arqueología de cuestión trascendental” en Pensamiento. Revista de Investigación e Información Filosófica, Universidad Pontificia de Comillas, vol. 67, núm. 254, pp. 116 y ss.

5 Cfr. Foucault, M., Les mots et les choses, Paris, Gallimard, 1999, pp. 249-261

${ }^{6} C f r$. "À propos de la généalogie de l'éthique" en $D E$, IV, p. 618.

7 Deleuze, G., op. cit., p.151.
} 
fundo que él (por ejemplo la historia o la economía); problematización que abre el espacio de una pertenencia y en él mora, pero también efectiva tarea y deber del pensar. Ethos, pues, del pensamiento.

Pues bien, una de las variantes concretas de esta problematización moderna del pensamiento viene a recogerse en la siguiente pregunta: ¿cómo se relaciona el pensamiento con la historia? Con ello se interrogará a la filosofía sobre «cómo es posible que el pensamiento tenga una historia, ¿cuál es el precio, para la filosofía, de una historia del pensamiento?» 8 , pero también, a la historia, sobre «¿cuál es el efecto, en la historia, del pensamiento y de los acontecimientos que le son propios?» ${ }^{9}$.En el horizonte de esta doble preocupación se determinará la empresa foucaultiana como una «Historia del pensamiento» ${ }^{10}$, que habrá de tomar a su cargo la doble cuestión señalada: la de la historicidad de un pensamiento que, siendo histórico, hace, además, historia; y ello en un modo muy señalado -enteramente distinto del hegeliano y del heideggeriano- y como pliegue crítico. Ello comprometerá la tarea de una historia del pensamiento con su propio presente, introduciendo el acontecimiento, justamente el del pensamiento, en la historia. Y es que «hay acontecimientos del pensamiento» ${ }^{11}$.

Historia, pues, del pensamiento, pero ni como historia de las representaciones ni como historia de las mentalidades, sino como historia de la problematizaciones -siendo la problematización, no la resolución de las cuestiones, el elemento diferencial del pensamiento12-, «a cuyo través el ser se da como experiencia, es decir, como pudiendo y debiendo ser pensado» ${ }^{13}$. La problematización abre entonces a un poder y a un deber con respecto al ser: a un poder y deber ser pensado, y se halla al fondo del movimiento de la historia. Un poder y un deber que se hurta en la ausencia del juego de la problematización. Ésta, cuando se ejerce, no procurará normas, valores o guías de acción, sólo abrirá a una experiencia, que nos afectará y pondrá en movimiento, no hacia otro mundo, sino hacia un mundo otro ${ }^{14}$, a construir en común. Tal experiencia no es sino la de lo intolerable en nuestro presente, aquélla que, lejos de producir complacencia, desencadenará una «voluntad política» 15 que, por sí misma y como tal, habrá de definir lo que es preciso hacer. Se juega aquí un muy determinado vínculo entre la problematización y la acción, desde el momento en que la problematización es «la libertad con respecto a lo que se

\footnotetext{
8 Foucault, M., "Préface à 1 «Histoire de la sexualité»" (première rédaction) en DE, IV, p.581.

9 Ibidem.

10 "Le souci de la vérité" en $D E$, IV, p. 668.

11 "Préface à ......" en $D E$, IV, p. 580.

12 "Polémique, politique et problématisations" en DE, IV, p. 597

13 Histoire de la sexualité II. L'Usage des plaisirs, Paris, Tel/Gallimard, 1999, p.13.

14 Cfr. Le courage de la verité. Cours au Collège de France. 1984, Paris, Gallimard/Seuil, 2009 , pp. 227-228 y 281-395.

15 "Le souci de la verité" en $D E$, IV, p. 677.
} 
hace» ${ }^{16}$. No se vincula entonces a la dominación, y no es manipulación de la voluntad, sino contribución a la formación de un querer, justamente un querer político. De este modo, como problematización, como relación crítica del pensamiento con la verdad se juega el ser mismo del sujeto político, no sin más su conocimiento (relación, pues, ontológica entre el sujeto y la verdad, no gnoseológica17, en la que «aletheia se convierte en ethos» ${ }^{18}$ ). No ha de extrañar entonces que Foucault señale que el dire vrai involucrado en la problematización plantea una «cuestión filosófica fundamental» ${ }^{19}$, justamente aquella de la relación entre la verdad y la libertad.

Tal ejercicio de la libertad -el más alto- como cuidado de la verdad, exige y comporta una «toma de distancia», justamente la del pensamiento, que hace ver, hace ver lo que no se veía, no por oculto o invisible, sino por habitual, por cotidiano, por demasiado evidente. En ese sentido, el pensamiento como problematización no ha de considerarse un hábito, sino la libertad con respecto a los hábitos y la condición del ejercicio del juicio y la acción:

El pensamiento no es lo que habita una conducta y le da un sentido; es más bien lo que permite tomar distancia con respecto a esta manera de hacer o de reaccionar, dársela como objeto de pensamiento e interrogarlo sobre su sentido, sus condiciones y sus fines. El pensamiento es la libertad con respecto a lo que se hace, el movimiento por el cual nos desprendemos de ello, lo constituimos como objeto y lo reflexionamos como problema $^{20}$.

Con todo, en otros textos la problematización aparecerá como un verdadero hábito de pensamiento, al margen de todo movimiento reflexionado, que regirá como condición de posibilidad de la experiencia ${ }^{21}$. Así, las «formas históricas de la problematización» se presentarán como las impensadas maneras de encarar lo real, de interpretarlo como esto o aquello, a la base de un conjunto de percepciones, reflexiones y acciones. Dominio de reglas, que hay que distinguir de lo que se ha llamado doxa, de las comunes maneras de hacer, percibir y reflexionar, y que es el propio de una episteme cristalizada e inmediatamente práctica, convertida en una suerte de automatismo de los hábitos. Se toca de nuevo aquí el problema de la libertad, desde el momento en que la problematización, como forma a priori de nuestro habérnoslas con lo que hay, como forma de nuestra experiencia, se define como un pensamiento mudo, no pensado, que constituye un sólido sistema de la participa-

\footnotetext{
16 "Polémique, politique....", en DE, IV, p. 597.

17 Cfr. L’herméneutique du sujet. Cours au Collège de France. 1981-1982, 2001, pp. 3-42.

18 "Les techniques de soi" en $D E$, IV, p. 800

19 Le gouvernement de soi et des autres. Cours au Collège de France. 1982-1983., Paris, Gallimard/Seuil, 2008, p. 64.

20 "Polémique, politique...." en DE, IV, p. 597.

${ }^{2}$ Cfr., por ejemplo, “Est-il donc important de penser?", en DE, IV, pp. 180-181.
} 
ción en la dominación, de una participación más monstruosa que la dominación misma, la de la obediencia, cómplice de aquélla. Frédéric Gros se ha referido a la obediencia (no a la dominación) como el concepto político «más esencial en Foucault» $22 \mathrm{y}$ a una monstruosidad que hay que buscar no tanto del lado de los dirigentes cuanto de los dirigidos, a la monstruosidad de aquello que genera, por acción o por omisión, la más terrible y general atrocidad, la que nace de lo más banal, de lo más cotidiano, de lo menos monstruoso. Monstruosidad que no ha de reconducirse entonces a ningún monstruo moral o a maldad alguna, sino a un operar automáticamente bajo una forma de problematización dada, en ausencia de «reproblematización»-la problematización pero esta vez en su forma crítica y objetivadora. En esta consideración de lo que es «el verdadero enigma» de la política, el «verdadero escándalo» como el «abuso de la obediencia», se halla «la razón por la que Foucault, como pensador político, se coloca al lado de Alain y de Hannah Arendt $\gg 23$.

Es preciso, por tanto, distinguir un doble aspecto en la problematización, o dos determinaciones de la misma en el pensamiento de Foucault, de ello dependerá una justa estimación de la importancia del pensar en el francés, de la importancia del pensar para la acción y la libertad. Lo hacemos con Potte-Bonneville. Este, con toda justicia, se referirá a un «sentido reflexivo» de la problematización ${ }^{24}$, que se define en todos esos textos de Foucault en que la tarea del pensar se muestra como «trabajo de problematización y de perpetua reproblematización» 25 , siendo dicha tarea socrática - «la de un retomar de raíz la manera en la que los hombres problematizan su comportamiento», la de un «sacudir los hábitos» $26_{-}$, lo que da su «sentido» al pensamiento:

Creo que el trabajo que hay que hacer es un trabajo de problematización y de perpetua reproblematización (...) si el trabajo del pensamiento tiene un sentido diferente de aquel que consiste en reformar las instituciones y los códigos es el de retomar de raíz la forma en la que los hombres problematizan su comportamiento (su actividad sexual, su práctica punitiva, su actitud por relación a la locura).27

Pero Potte-Bonneville se referirá a otro sentido de la problematización en Foucault, digamos un sentido no reflexivo y ontológico, que se presenta en todos

\footnotetext{
22 Frédéric Gros, "Foucault. L'abus d'obéissance" en Libération,www.liberation.fr/page.php? Article $=216729$

23 Ibidem.

24 Potte-Bonneville, M., Michel Foucault, la inquietud de la historia, Buenos Aires, Manantial, 2007, p. 225.

25 Foucault, M., “Á propos de la généalogie...” en $D E$, IV, p. 612.

26 Ibidem.

27 Ibid.
} 
esos textos en los que la problematización se determina como un sistema de acción inmediatamente involucrado en la acción misma, como ese pensamiento inadvertido, no tematizado, que encontraríamos, no en las formulaciones teóricas de la filosofía o de la ciencia, sino «en todas las maneras de hacer, de decir, y de conducirse» 28 . Tal pensamiento es el que «anima los comportamientos cotidianos», y se halla presente incluso «en las instituciones más banales» ${ }^{29}$, definiendo un espacio de juego, el de lo verdadero y lo falso ${ }^{30}$, donde se juegan y deciden no tanto el conocimiento del sujeto, cuanto su ser mismo y sus relaciones posibles, «las relaciones recíprocas entre el sujeto y el objeto» 31 . Tal determinación del pensamiento acerca a Foucault al pensamiento de Heidegger. Así, Potte-Bonneville, siguiendo en este punto a Dreyfus y Rabinows, señalará que «estamos cerca, de hecho, de una definición del pensamiento como "claridad", como Lichtung, que abre, antes de cualquier intervención de la subjetividad, un campo de discurso y de acción en el seno del cual hombres, palabras y cosas podrán coordinarse» 32 .

Mas, si esto es así, no se entiende -y así lo señala Potte-Bonneville- por qué Foucault llama "problematización" a esta «apertura del pensamiento, que no parece (...) movilizar ninguna ruptura de la evidencia y, por el contrario, se presenta como el modo de aparición, primero y estático, de las cosas»: no tanto como el lugar de un problema cuanto como el espacio de un «puro don»33. En suma: ¿Por qué llamar a esa forma de aparición "forma de problematización», si justamente, tal como hemos visto en la caracterización del sentido reflexivo de la problematización, ésta parece comportar una toma de distancia crítica, un distanciamiento y una ruptura con la evidencia que la determinación de la problematización como Lichtung, como espacio de aparición primera, parece negarle? A nuestro juicio, ello no se debe a una inconsistencia teórica, ni a una falta de rigor por parte de Foucault. A este respecto, tal como señala Potte-Bonneville, es preciso no «confundir la "toma de distancia" invocada por Foucault con el acceso a una exterioridad radical, a una universalidad desde la cual el sujeto podría preguntarse lo que la historia ha hecho de él» ${ }^{34}$, mas tampoco neutralizarla en una consideración en la que no cabría distanciamiento alguno, desde el momento en que un conjunto de determinaciones a priori regirían de manera inevitable nuestras acciones y reflexiones. Todo se juega en entender que la problematización es ethos, al tiempo una pertenencia y una tarea que es deber ${ }^{35}$. Y ella puede ser, al tiempo, una pertenencia y un deber porque tal

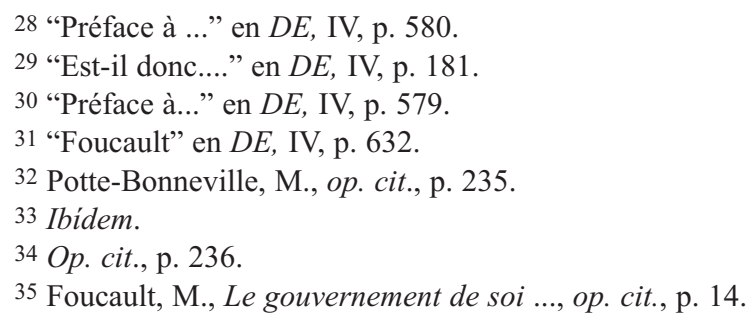


pertenencia se halla «desde el comienzo agrietada, fracturada, inquieta» 36 . En esta grieta de la pertenencia residiría «la posibilidad de la toma de distancia» 37 reflexiva. Ahora bien ¿por qué esta grieta, esta fractura de la evidencia en la evidencia misma?, ¿por qué esta imposibilidad de evidencia completamente tranquila?, ¿a qué se deben «las dificultades» 38 -que no el problema- en la evidencia de la evidencia? A nuestro juicio una respuesta coherente y ajustada a la integridad de los pronunciamientos foucaultianos sobre la noción de problematización pasa por comprender que la evidencia nace de una problematización y fue una vez problematización de una evidencia anterior, pasa por entender que las formas de la problematización, a cuyo través el ser se constituye como experiencia, son la cristalización, como un hábito impensado de pensamiento en nuestro hacer y decir, de lo que un día fue una práctica de pensamiento, una práctica de problematización. Y el que estemos llamados a la tarea y al deber infinito de la problematización dependerá de que ésta, al darse siempre en una "forma" -y esto es, de nuevo, una indicación de finitud- no abrirá a un problema -para el que serán posibles diferentes soluciones que arraigan en una misma forma de problematización- sin cerrarse a otros que, en un determinado momento, y por obra de una nueva problematización, serán definidos. Ahora bien, esta nueva determinación activa de lo problemático será incitada por un conjunto de «dificultades» inherentes a la problematización anterior, esta vez como plano de una evidencia necesariamente agrietada. "Incitada", la problematización es siempre respuesta a una dificultad dada, mas no es una respuesta automática, un mero epifenómeno superestructural, y por eso no se halla nunca determinada; es una respuesta libre y original a un conjunto de dificultades sociales, económicas y políticas, una respuesta a una interpelación de la realidad que se juega como pregunta en cuyo espacio se ha de definir -bajo una determinada forma de problematizaciónlo que no se definía simplemente por costumbre: una experiencia intolerable que moviliza, en el seno de lo político, discursos y acciones. La problematización abre, pues, a una nueva experiencia, mas tal apertura, hay que subrayarlo, implica una incitación de lo real, nace de una serie de "dificultades" en un dominio de acción vinculadas a factores económicos, políticos o sociales, que hacen que tal dominio pierda su familiaridad, se torne incierto.

Todo ello impone una extrema precaución a la hora de dar cuenta de afirmaciones que, fácilmente, desvinculadas del dispositivo textual en el que encuentran su lugar, podrían conducir a una impresión de idealismo en el pensamiento foucaultiano; afirmaciones como aquella en que se dice que «el estudio del pensamiento es el análisis de una libertad» 39 . Los textos foucaultianos deshacen todo posible malentendido:

\footnotetext{
36 Potte-Bonneville, op. cit., p. 238.

37 Op. cit., pp. 237-238.

38 Foucault, M., "Polémique...”, en DE, IV, p. 597.

39 Ibidem.
} 
Decir que el estudio del pensamiento es el análisis de la libertad no quiere decir que este se ocupe de un sistema formal que sólo tendría referencia a sí mismo. De hecho para que un dominio de acción, para que un comportamiento entre en el campo del pensamiento, es preciso que un cierto número de factores lo hayan tornado incierto, le hayan hecho perder su familiaridad o hayan suscitado en torno a él un cierto número de dificultades. Estos elementos dependen de procesos sociales, económicos o políticos. Pero ellos no juegan ahí más que un papel de incitación. Ellos pueden existir y ejercer su acción durante mucho tiempo, antes de que haya una problematización efectiva por el pensamiento. Y ésta, cuando interviene, no toma una forma única que sería el resultado directo o la expresión necesaria de estas dificultades; ella es una respuesta original o específica a menudo multiforme, a veces incluso contradictoria en sus diferentes aspectos, a estas dificultades que son definidas por ella por una situación o contexto y que valen como una cuestión posible. 40

Un fragmento de Est-il donc important de penser? aclara extraordinariamente sobre la importancia del pensamiento en la comprensión foucaultiana de la historia, acerca de su realidad, pero también acerca del doble sentido de la problematización indicado 41 . En este texto Foucault pone en juego una noción de crítica que se articula sobre la doble determinación de la problematización analizada. Así, el pensamiento se presenta, en primer lugar, como una forma de problematización dada en nuestros discursos y acciones cotidianos, se concibe como «modos de pensamiento adquiridos y no reflexionados» sobre los que reposan «las prácticas que aceptamos». La problematización es aquí, como forma o sistema que organiza nuestras prácticas, ese pensamiento que «se esconde a menudo pero anima siempre los comportamientos cotidianos», ese pensamiento implicado «incluso en los hábitos mudos y en «las instituciones más banales». Tal concepción del pensamiento reenvía fácilmente a la noción platónica de doxa, entendiendo por tal esa actitud en nuestro habérnoslas cotidiano con lo que hay en la que pasa inadvertida la estructura de presupuestos que sostiene tal habérselas, en la que pasan desapercibidas las reglas que rigen nuestras prácticas cotidianas, es decir, el saber, inmediatamente práctico, operatorio, que las posibilita, el saber habérselas con contenido en nuestro habérnoslas con las cosas y los otros, ese saber que constituye un plano de condiciones prácticas de posibilidad, el propio de lo que Platón llamó ideas.

Pero, por otra parte, el pensamiento se esbozará también en el texto referido en su modalidad crítica, como práctica de problematización y entonces ya no sólo como forma de problematización dada en el pensar y el actuar cotidianos. De este modo Foucault se referirá a una crítica que «consiste en ver sobre qué tipos de evidencias, de familiaridades, de modos de pensamiento adquiridos y no reflexionados reposan las prácticas que aceptamos» Con ello se trata de un peculiar ver, justamen-

\footnotetext{
40 Ibid.

${ }^{41}$ Cfr. "Est-il donc...", en DE, IV, pp. 180-181.
} 
te aquel que tiene por objeto, no las cosas (acaso las verdaderas cosas), sino lo invisible del pensamiento no reflexionado involucrado en nuestras prácticas; un ver referido entonces a las reglas que rigen nuestros discursos y acciones cotidianos, que habrá de comportar una interrupción, una ruptura con dicha cotidianidad y su visión (si bien ciertamente incitada en la cotidianidad y por ella); una toma de distancia por la que no seremos reenviados a ningún otro lugar, el de lo realmente verdadero más allá del espacio de las apariencias visibles, y por la que accederemos, en la forma de un paradójico paso atrás que no se mueve de su sitio, a las condiciones de aparición de lo que aparece. Es justamente a este ver, que es también un saber de orden objetivante, tematizante, a este saber que no es inmediato y operatorio saber habérselas con, a este saber crítico que lo es de la estructura de saber a priori implicado en nuestra experiencia, al que Platón llamó episteme: saber no de las cosas verdaderas más allá de las cosas de este mundo, sino de las reglas que rigen en nuestra experiencia cotidiana de las cosas, saber de las condiciones de posibilidad de las cosas.

Y esta crítica, así considerada, como un ver lo que, por lo común, pasa desapercibido, habilita, y ello en tanto que mero ver y como distanciamiento, lo que Foucault llama una "transformación "real"42. El pensador francés se referirá, así, a una "crítica radical", real, muy distinta de aquella, puramente ideal, que se desenvolvería en el plano del mero ajuste de las representaciones con la "realidad". Tal consideración material de la crítica supone y exige la liberación del pensamiento respecto de la «sacralización de lo social como única instancia de lo real»y, con ello, de esa concepción de la historia como Historia social, reconocible en un cierto marxismo ${ }^{43}$, según la cual la realidad del pensamiento se vería reducida al estatuto de un mero epifenómeno superestructural -un mero efecto de superficie- explicable a partir de la realidad, de la fuente de todo verdad, que sería la del «contexto económico y social» ${ }^{44}$. De acuerdo con esta concepción, las transformaciones reales se jugarían a otro nivel que el del pensamiento, el propio de una dialéctica real entre las fuerzas productivas y las relaciones de producción.

Pero tal liberación de esa explicación social y contextual, que niega la realidad del pensamiento, no ha de abocar a Foucault a un planteamiento antropológico fundamental, donde el pensamiento del sujeto vendría a constituir la realidad fundamental, a la que todo lo que hay, de un modo u otro, acabaría por reducirse, y en el que la historia se presentaría como el abrigo de dicho sujeto y el espacio de su reco-

\footnotetext{
42 Y la cuestión es: ¿cómo algo que supone un distanciamiento con respecto a lo real puede constituir una transformación real?

43 Juntamente ese marxismo que habría olvidado la lección de Marx que tan a fondo aprendió Althusser: aquella referida a la noción de revolución teórica cfr. Foucault, M., "Introduction" en $L$, archéologie du savoir, Paris, Gallimard, 1999, p.12.

44 "Préface à ... (première rédaction)" en $D E, \mathrm{IV}, \mathrm{p} .579$.
} 
nocimiento 45 . Frente a esta consideración, Foucault operará una reducción nominalista de la antropología fundamental46, que le permitirá mantener a distancia el postulado del hombre como sujeto. Todo ello hace que Foucault se sitúe no sólo al margen de la concepción paradójica e improductiva de un pensamiento finito y, al tiempo, originario, sino, en general, del «dilema dominante de una antropología filosófica y de una historia social» 47 .

La superación de tal dilema se produce bajo la forma de esa crítica no antropológica que busca en nuestras prácticas, discursos e instituciones la estructura fundamental de pensamiento que los sostiene e intenta cambiarla. Ahora bien, ese cambio constituye mucho más que un cambio en el seno del puro pensamiento: es trasformación de la realidad misma. Es más, Foucault considerará que no puede haber una verdadera transformación si no hay, ante todo, un cambio en el modo de pensar. Siendo así las cosas, la crítica, como crítica radical, habrá de funcionar como instancia de transformación de realidad, y su eficacia habrá de depender de su poder de modificación de los modos de pensar a la base de nuestras prácticas cotidianas; y es que una transformación que no afecta a tales modos de pensar es sólo una transformación superficial.

Pues bien, esta doble determinación del pensamiento, que hallamos en Est-il donc important de penser?, y que es absolutamente imprescindible para comprender las transformaciones radicales en la historia (la historia como el lugar del acontecimiento, del initium), encuentra en el análisis de los tres principios de la historia del pensamiento de la primera versión de Préface à l' "Histoire de la sexualité" su expresión más ordenada, completa y rigurosa. El pasaje del que ahora nos ocupamos 48 llama, ya desde su comienzo, poderosamente la atención, desde el momento en que Foucault inquieta la comprensión más habitual de su modo de proceder, al indicar que plantear la cuestión del pensamiento «de esta manera» implica «la puesta en obra de algunos principios enteramente generales» en la práctica de la historia del pensamiento. Esta manera de expresarse ha de resultar, cuanto menos, chocante: principios enteramente generales, pues ¿cómo y en qué sentido una empresa crítica que se inscribe en la corriente nominalista ${ }^{49}$ y tiene en la discontinuidad no solo su objeto sino también su método, puede constituirse y articularse a partir de principios generales? ¿Se trata de un desliz nominal por parte de Foucault o de una incoherencia? A nuestro juicio no se trata ni de lo uno ni de lo otro y nuestra intención es ocuparnos de este asunto en el tercer apartado de este trabajo. De momento nos contentamos con exponer y analizar someramente tales principios, sin entrar todavía en el asunto de su estatuto y función.

\footnotetext{
45 L, archéologie du savoir, Paris, Gallimard, 1997, pp. 9-28.

46 "Préface á ..." en $D E$, IV, p. 579

47 Ibidem.

48 Ibid., pp. 580-581.

49 Sobre este asunto volveremos en el tercer apartado de este estudio introductorio.
} 
Un primer principio general sería el que Foucault presenta como «principio de la irreductibilidad del pensamiento» 50 . Irreductibilidad de éste hasta en la experiencia más cotidiana: no es posible reducir el pensamiento a la experiencia, no es posible una experiencia que no esté atravesada y organizada por el pensamiento. No hay, pues, experiencia sin que en ella juegue el a priori de la problematización. Estamos, por tanto, ante un principio crítico por relación a la experiencia -de sí mismo y de los demás como sujetos de percepción, de acción y de conocimientos. Así, Foucault afirmará que «no hay experiencia que no sea una manera de pensar y que no pueda ser analizada desde el punto de vista de una historia del pensamiento». La historia del pensamiento como problematización se concibe así como el dominio de formación, desarrollo y transformación de las formas de la experiencia.

Hay, en segundo lugar, un «principio de singularidad de la historia del pensamiento» ${ }^{51}$. Según este principio el pensamiento tiene, ciertamente, una historia, pero una historia «que le es propia»: la historia lo es entonces, irreductiblemente, del pensamiento, pero hay que entender bien que esa historia en la que el pensamiento mantiene su especificidad no es una historia del mero pensamiento, $\mathrm{y}$, en ella, se juega la historia sin más (de manera consecuente con todo lo que hemos señalado acerca de la relación del pensamiento con la experiencia). Ahora bien, que el pensamiento tenga una historia no significa que él se halle desprovisto de cualquier forma universal -cuya puesta en juego será, sin embargo, ella misma histórica. Por otra parte que esta historicidad sea propia no significa que el pensamiento no guarde relación con otras instancias de orden económico, social o político, sino que no se reduce a las mismas, manteniendo con ellas «relaciones complejas que dejan siempre su especificidad a las formas, a las transformaciones, a los acontecimientos del pensamiento: (...) hay acontecimientos del pensamiento», señala Foucault.

Por último, Foucault se referirá al «principio de la historia del pensamiento con actividad crítica ${ }^{52}$, que implica el reconocimiento explícito del carácter decisivo del trabajo crítico en las transformaciones históricas; y es que éstas «no podrían efectuarse más que por un trabajo del pensamiento sobre sí mismo» que se determina «como análisis de las condiciones históricas según las cuales se constituirían las relaciones con la verdad, con la regla y consigo mismo», tal análisis crítico «no fija fronteras infranqueables y no describe sistemas cerrados, ella hace aparecer singularidades transformables».

Estos tres principios nos permiten hacernos una idea cabal de la importancia del pensamiento en los textos foucaultianos. Importancia, por su realidad, por su peso ontológico y poder de transformación de lo real, pero importancia también por

\footnotetext{
50 Ibid., p. 180.

51 Ibid.

52 Ibid.
} 
aquello que en el pensar se halla en juego: el ser mismo del hombre, no como substancia, sino como sujeto de acción que halla su definición en el espacio de juego de la problematización 53 . Y es que, señala Foucault, «el hombre es un ser pensante» 54 , siendo el pensamiento no «lo que nos hace creer lo que pensamos ni admitir lo que hacemos, sino lo que nos hace problematizar incluso lo que nosotros mismos somos». En la problematización se alcanza, pues, libertad. De ahí que la tarea del pensar haya de ser, ante todo, la de un «presentir el peligro que amenaza en todo lo que es habitual», en lo más banal, el peligro para el ser mismo del hombre, pues como banalidad desaparecen de forma masiva los hombres en el mundo y la dominación más extensa puede prosperar. De ahí que la actividad del pensar no puede ser considerada por Foucault algo elitista y destinado a unos pocos, sino, sencillamente, lo que hace hombres a los hombres, es decir, lo que los entrega a un ejercicio de responsabilidad ante lo que hay al que todos están llamados, el de la «libertad humana», en la que Foucault cree «sólidamente» 55 . Por el pensar, a través de la práctica de la problematización, nos abrimos a un ejercicio, el de la libertad, que nos hace hombres. Es este asunto el que abordaremos en el siguiente apartado, tomando apoyo en los desarrollos del curso del año 83 en el Collège de France.

\section{De los efectos del pensamiento o de su actualidad: Filosofía y política}

Una de las cuestiones generales del curso del año 83, quizá la cuestión fundamental -a nuestro juicio el eje que recorre todo el curso- es el problema de «lo real de la filosofía»56: ¿en qué consiste eso real?, ¿qué articulaciones y separaciones pone en juego?, ¿qué noción del saber filosófico? En una primera aproximación se podría decir que la realidad de la filosofía se define en ese curso en relación a una política (y no tanto en referencia a la contemplación de la verdad), que, en ningún caso, ha de identificarse con ella. Y es que la filosofia no es política pero se relaciona con la politica, tal es uno de los leitmotivs del curso, precisamente el que ha de conducir el análisis prioritario en el mismo de la conexión filosofía-política, como análisis de una diferencia irreductible y de una relación.

Tal juego entre lo filosófico y lo político se deja ver, ya desde la primera lección del curso, en el análisis de la noción kantiana de actualidad filosófica. En tal análisis vemos liberarse una concepción del tiempo como acontecimiento en el que la filosofía, como tarea crítica de problematización, ha de jugar un papel decisivo.

\footnotetext{
53 En esa medida no podrá ser el sujeto de aquélla y bien puede decirse que la problematización no es una propiedad del hombre sino el hombre una propiedad de la problematización.

54 “À propos de la généalogie..." en $D E$, IV, p. 612.

55 "Interview de Michel Foucault" en DE, IV, p. 693.

56 Le gouvernement de soi ..., op. cit., p. 209.
} 
De este modo Foucault se referirá a la novedad del texto kantiano Beantwortung der Frage: Was ist Aufklärung?; novedad desde el momento en que en este artículo de revista se abre un nuevo tipo de interrogación filosófica, que es justamente aquella que el propio Foucault practica: la interrogación sobre el propio presente, en su radical diferencia con respecto a todo aquello que él no es (pasado y futuro) y, por eso, como acontecimiento que, rompiendo la línea del tiempo, constituye un verdadero comienzo en la historia. Ahora bien, con tal interrogación no se trata sin más de determinar el presente como acontecimiento, sacando a luz el elemento que lo dotaría de singularidad histórica. La cuestión es mucho más compleja, y ello desde el momento en que se ha de mostrar «el sentido, el valor, y la singularidad filosóficas» ${ }^{57}$ de tal acontecimiento. Acontecimiento, pues, pero «acontecimiento filosófico al que pertenece el filósofo que habla». La posibilidad de la novedad en la historia queda así enlazada con la práctica de la filosofía. Puede definirse así el nuevo objeto de la interrogación filosófica: no sin más la actualidad, sino la «propia actualidad discursiva» 58 de la filosofía.

Ello supone desmarcarse, para empezar, de una determinación excesivamente teorética de la filosofía, así como de la imagen del filósofo que le es correlativa: la de aquel que «vuelve la mirada hacia otra realidad y se separa de este mundo» 59 . Pero, igualmente, tal como vimos en el apartado anterior, desvincularse de esa concepción de la filosofía como un mero efecto de superficie sin verdadera realidad y, por eso, como algo derivado y producido a partir de instancias exteriores a ella (instancias económicas, sociales, psicológicas, políticas, etc.), que vendrían a reducir su poder de efectuación, su actualidad.

Frente a estos modos de concebir la filosofía, el curso del año 83 pondrá en juego una noción de ésta en la que el asunto de su ergon -no de su mero logos-cobrará toda su relevancia. Se tratará aquí de su actividad, específica e irreductible, de lo real (le réel) de ella. Así las cosas, hallaremos en dicho curso, en el marco de una lectura de la Carta VII de Platón, valiosas indicaciones para la comprensión de tal determinación de la filosofía, que es también -al menos así lo consideramos nosotros- la misma que podemos encontrar en los últimos pronunciamientos foucaultianos de actualidad sobre la práctica filosófica y el intelectual, en las entrevistas, conferencias y artículos de finales de los 70 y principios de los 8060 . En el trabajo histórico del curso del 83 Foucault elabora su última comprensión de la función del intelectual en relación a la política. Al respecto, el título de este curso es bien significativo: Le gouvernement de soi et des autres.

\footnotetext{
57 Ibidem, p. 14.

58 Ibid.

59 Ibid, p. 236

60 Por ejemplo en Polémique, politique et problématisations, pero también en Le Souci de la vérité.
} 
La señalada lectura foucaultiana de la Carta VII de Platón se concentra en el problema del ergon de la filosofía. Ésta, si aspira a tocar lo real y ser algo más que mero logos, habrá de responder al llamado de la política61. Ahora bien, la política llama a la filosofía porque la necesita, y la necesita porque ella no es capaz de producir, de acuerdo con sus propios mecanismos, un dire vrai, un decir la verdad y un decir verdadero en el campo político. La verdad habrá de venir entonces de afuera, justamente de la filosofía. Tal es la exigencia de la finitud en la ciudad, que emerge con hiriente claridad en el tiempo en que Platón piensa, imponiendo la obligación de discernir entre el hecho y derecho, entre lo que es y lo que no es, ni será jamás, pero impone una obligación, un deber: el de mirar a las ideas como única manera de salir de la dominación que impera en el mundo. De este modo, el recurso a la filosofía se habrá de presentar como la consecuencia de una imposibilidad62, la de un dire vrai propiamente político, la de una ciudadanía que espontáneamente y sin cuestionar los usos de la ciudad, es decir, sin establecer una distancia con respecto a ellos, dice la verdad (dire vrai). Siendo así las cosas, el dire vrai en el orden de la política no será entonces propiamente político, sino filosófico: «La parresía (...), el dire-vrai en el orden de la política sólo puede estar fundado en la filosofía» 63 . Ello, evidentemente, no puede significar que la realidad de la verdad ya nada tenga que ver con la política, sino que «el dire-vrai en el campo de la política sólo puede ser de hecho el dire-vrai filosófico» 64 .

A partir de estos parámetros se comprende que la respuesta de la filosofía al llamado de la política se imponga como una «obligación interna» de aquella, como un deber: deber de intervenir en lo que es -en el campo político- ante una evidencia intolerable, ante la percepción de un mal, de una enfermedad, y ante la constatación de que del hecho no podrá surgir el derecho y de la opinión no podrá surgir la verdad; ante la constatación de que la ciudad no podrá producir, sin dificultad, es decir, sin problematicidad y problematización, verdad, esa que enlaza con el ejercicio de la libertad. Deber, pues, y no deseo de posesión, como motivo para la intervención política, deber constitutivo de la filosofía de «no ser simplemente logos, sino también ergon» 65 :

El motivo para intervenir en el orden de la política, no es el deseo del filósofo por relación al que se dirige, sino la obligación interna de la filosofía como logos de ser además ergon 66 .

\footnotetext{
61 Ibid, pp. 201-202.

62 Ibid., p. 200

63 Ibid.

64 Ibid.

65 Ibid., p. 209.

66 Ibid.
} 
De este modo, Foucault, con el Platón de la Carta VII, planteará la cuestión de «lo real de la filosofía» 67 , de una filosofía que no es puro logos. Ahora bien, sería preciso definir con rigor tal cuestión. Con ella no se trata del problema de la relación de la filosofía con un referente o unos referentes reales que permitirían determinar la verdad o la falsedad del discurso filosófico. Se trata, antes bien, de preguntarse sobre aquello que es, en su realidad misma, la voluntad y la actividad de direvrai, el acto de veridicción: «¿cómo, de qué manera, sobre qué modalidad se inscribe en lo real el dire-vrai filosófico, esta forma particular de veridicción que es la filosofía?» 68

Pero ¿en qué consiste el hacer de la filosofía, esa tarea que se impone como un deber y por la que la filosofía alcanza su realidad, su actualidad? Lo primero que habría que decir es que tal hacer se da como un cierto desfase, en una cierta ruptura con las estructuras de la inmanencia: con la inmanencia del logos, «del juego intrínseco del logos consigo mismo» ${ }^{69}$; con la inmanencia también de lo político, que la retórica, al menos desde el punto de vista de la filosofía, nunca rompe -en tanto «instrumento por el cual aquel que quiere ejercer el poder no puede hacer otra cosa que repetir muy exactamente lo que quiere la multitud o lo que quieren los jefes o lo que quiere el príncipe» ${ }^{70}$. Frente a ello, la actividad de la filosofía se ejerce como genuina relación con algo otro, en un «juego propio en relación a la política»:

La prueba de lo real que es la filosofía, no es su eficacia política, es el hecho de que ella se introduce, en su diferencia propia, en el interior del campo político, y que ella tiene su juego propio por relación a la política ${ }^{71}$

Ahora bien, durante mucho tiempo se ha creído que lo real de la filosofía consistía en poder decir la verdad esencial sobre la ciencia o la política, «la verdad sobre la verdad, la verdad de la verdad» ${ }^{72}$. Los textos platónicos explorados abren otras posibilidades: se tratará ahora de decir la verdad $a$ la política, y no tanto de manifestar su esencia o fundamento en una revelación que habría de funcionar como prescripción para la ciudad. El filósofo no ha de imponer a los otros una verdad que sólo estaría a su alcance (¿con qué derecho podría hacerlo?), no ha de hablar para «imponer -en el punto de partida de la ciudad o como su cuadro institucional- las leyes fundamentales». Aquél no arribará a la ciudad como el ilumina-

\footnotetext{
67 Ibid.

68 Ibid., p. 210

69 Ibid.

70 Ibid., p. 211.

71 Ibid.

72 Ibid.
} 
do que, viniendo del mas allá, se presenta «llevando las tablas de la ley ya escritas ${ }^{73}$ (tal es la figura del filósofo que se dibuja, por ejemplo, en ese contrapunto a la Carta VII que es el Alcibiades ${ }^{74}$ ), su función no será la del nomoteta y, lejos de establecer prescripciones, programas o guías de conductas, se dirigirá a la «voluntad política» 75 , mas no para manipularla o embotarla, sino para animarla y vivificarla y, con ello, para «animar y hacer vivir la politeia» ${ }^{76}$, pues ella depende de la vida de esa voluntad. No ha de extrañar entonces que Foucault señale en este contexto de análisis que «la cuestión de la filosofía no es la cuestión de la política, sino la cuestión del sujeto de la política» 77 y que indique, asimismo, que la transformación que se juega en la filosofía no es tanto conversión de la mirada, cuanto de la decisión ${ }^{78}$. De lo que se trata entonces con la filosofía no es de la contemplación de la verdadera realidad, de la captación de las normas esenciales que han de hacerse valer como la ley en la ciudad, sino «simplemente del sujeto mismo», de la constitución del sujeto político en cuanto tal: «el trabajo de sí sobre sí es lo real de la filosofía» 79 , por ella uno llega a ser un sujeto de verdad que es también de decisiones $\mathrm{y}$ acciones comunes.

Se contribuye de este modo, con la práctica de la filosofía, a la formación de una voluntad política, que ha de definir, por si misma, y como tal voluntad política, las mejores maneras de ejercer el poder. La filosofía no puede ni debe arrogarse el derecho de tal definición. Y es que «las relaciones entre filosofía y política no han de buscarse en la capacidad eventual de la filosofía para decir la verdad sobre las mejores maneras de ejercer el poder. Después de todo, es la política, por sí misma, la que ha de saber y definir cuáles son las mejores maneras de ejercer el poder» ${ }^{80}$.Se delimita así el espacio de un juego complejo, de una «relación necesaria, fundamental, que es sin duda constituyente de la filosofía y de la práctica política en Occidente»81; relación sin posibilidad de coincidencia o reducción, pues la filosofía no existe como discurso de verdad sobre la política, sino como un decir verdadero y un decir la verdad «con respecto al poder, por relación al poder, en una espacio de cara a cara con él o de intersección con él»82. En tal espacio la filosofía

\footnotetext{
73 Ibid., p. 236

74 «en el Alcibíades el problema era saber, una vez que el sujeto había alcanzado el momento donde él era capaz de contemplar la realidad, cómo podía descender y aplicar efectivamente lo que había visto a la vida cotidiana», Ibid., p. 223

75 Ibid., p. 216

76 Ibid., p. 217

77 Ibid., p. 295

78 Ibid., p. 223

79 Ibid., p. 224

80 Ibid., pp. 263-264.

81 Ibid., p. 264.

82 Idem.
} 
inquietará al poder problematizando su uso, pero no usurpará su lugar, acaso dándose por tarea « decir cómo gobernar, que decisiones tomar, qué leyes adoptar, que instituciones poner a punto» 83 .

Esta forma de relación es aclarada por Foucault en su lectura del motivo del Filósofo rey en la Carta VII. En referencia a este texto lo primero que sería preciso hacer notar es que, en él, esta conexión entre la práctica de la filosofía y el ejercicio del poder se vincula al cese del mal (kakós) ${ }^{84}$, constituyendo la condición de una «política justa» 85 . Ahora bien, esa salida del mal, que es también salida de la minoría de edad del pensamiento o del modo de estar en el mundo de la doxa, no dependerá de una «coincidencia de los contenidos», de un «isomorfirmo de racionalidades o de «una identidad del discurso filosófico y el discurso político» ${ }^{86}$. Foucault aclara sobre este punto recorriendo los conocidos pasajes de la Carta VII y de República, $V$ sobre el filósofo rey. En relación con el pasaje de la Carta VII, Foucault opera un desplazamiento sutil, pero decisivo, en la lectura habitual de este motivo, al hacer notar un error de traducción. Y es que en la edición francesa de la Carta VII ${ }^{87}$, se señala que los males no cesarán para los hombres en el mundo «mientras la raza de los puros y auténticos filósofos no llegue al poder o los jefes de las ciudades, por una gracia divina, se pongan a filosofar verdaderamente» (avant que la race des purs et authentiques philosophes n'arrive au pouvoir ou que les chefs des cités, par une grâce divine, ne se mettent à philosopher véritablement). Foucault propone, como traducción más ajustada: «mientras la raza (to genos) de los que filosofan recta y verdaderamente» (avant que la race de ceux qui philosophent droitement et vraiment). Ya no se trata entonces, en la propuesta foucaultiana, de la casta de los filósofos puros, acaso portadores de un saber excepcional sobre las leyes de la ciudad, sino de aquellos que ejercen un poder que saca del mal, y ello en tanto que, y mientras que, filosofan, es decir, practican la filosofía. El linaje, la raza (to genos), ya no parece ser la de unos hombres excepcionales en contacto con el saber fundador de la ciudad, sino la de los hombres sin más, que hacen cesar el mal en la ciudad en la medida en que piensan, filosofan.

Pero Foucault se referirá también al texto de la República ${ }^{88}$, el más famoso y fundamental, del que el fragmento de la Carta VII señalado es un eco fiel con peque-

\footnotetext{
83 Ibid., p. 266.

84 Cfr. Platón, Carta VII, 326b. Se trata de la salida de ese mal que crece en la ausencia del verdadero filosofar. Mucho tiempo después Hannah Arendt denominó a esta especie de mal mal banal. Cfr., por ejemplo, "El pensar y las reflexiones morales" en De la historia a la acción, Barcelona, Paidós, 1995, pp. 109-137.

85 Foucault, M. : Le gouvernement de soi ...., op. cit., p. 272.

86 Ibidem.

87 Platón, "Lettre VII" en Oeuvres Complètes (Tome XIII, 1 a partie. Trad. J. Souilhé), Paris, Les Belles Lettres, 1960, 326b.

88 Platón, República, $V, 473 \mathrm{c}$.
} 
ñas variantes. Foucault vuelve a poner el acento sobre el mismo punto, operando un nuevo desplazamiento habilitado por lo que el filósofo francés considera una traducción más ajustada. La propuesta foucaultiana, alternativa a la que hallamos en la edición francesa ${ }^{89}$ (en que se dice que los males no cesarán en las ciudades «a menos (...)que los filósofos lleguen a ser reyes en los estados, o que aquellos que están llamados a ser reyes y soberanos lleguen a ser verdaderos y serios filósofos, y que se vea reunida en el mismo sujeto el poder político y la filosofía», a moins (...) que les philosophes ne deviennent rois dans les États, ou que ceux qu'onappelle à présent rois et souverains ne deviennent de vrais et sérieux philosophes, et qu'on ne voie réunis dans le même sujet la puissance politique et la philosophie), se esfuerza en mostrar que la traducción de «aquellos que están llamados a ser reyes o soberanos» corresponde al griego dinastai, que debería verterse más bien como «aquellos que ejercen el poder». Éstos, en la traducción de Foucault, son los que han de ponerse a «filosofar de forma auténtica y hikanôs, competente» 90 (no se trata entonces, tal como se dice en la edición francesa, de que éstos «lleguen a ser verdaderos y serios filósofos»). Estas correcciones de traducción pretenden subrayar lo que al final del fragmento platónico se delimita en su figura más diferenciada: se trata de que se vean reunidas, en un mismo sujeto -el sujeto de la política que somos todos nosotros-, dunamis politikê (el poder político) kai philosophia (y la filosofía)»91

Todo ello nos pone sobre la pista de que la identidad en juego no puede ser aquí la de unos saberes o unas racionalidades, de modo que la filosofía viniera a constituir una suerte de «racionalidad política», según la cual «en el soberano será el filósofo el que le dirá lo que tiene que hacer como soberano y (...) la parte de él mismo que será soberana no hará otra cosas que hacer pasar en los actos mismos de su gobierno lo que le dirá el discurso filosófico» ${ }^{92}$. Frente a este modo de presentar la reunión de la filosofía y la política, se tratará ahora de otra identidad, no aquella de una «adecuación entre el discurso filosófico (...) y la práctica política»-con lo que ello comportaría: la reducción de la práctica a la teoría-, sino aquella otra que es la de un único sujeto, en el que coinciden, en una diferencia irreductible, la práctica de la filosofía y el ejercicio del poder. La coincidencia se da entonces entre aquellos que practican la filosofía y, por eso, son verdaderos filósofos, y aquellos que ejercen el poder (y ello en tanto practican la filosofía). Coincidencia, pues, entre sujetos, no entre racionalidades.

Lo que, entonces, cobra mayor relevancia en la lectura foucaultiana de estos textos de Platón es la idea de que «quien practica la filosofía sea el que ejerce el poder y aquel que ejerce el poder sea también alguien que practica la filosofía»., es

\footnotetext{
89 Platón, Ouvres Complètes, Tome VII-1 ${ }^{\mathrm{a}}$ partie, trad. E. Chambry, Ed. cit., 473c

90 Foucault, M., op. cit., p. 271.

91 Idem.

92 Idem.
} 
decir, la idea de que uno es sujeto político en la medida en que también lo es de la filosofía. Ahora bien, de esto no puede inferirse «que lo que él sabe en tanto filósofo será la ley de su acción y de sus decisiones política» ${ }^{93}$. Lo que se revela ahora como una exigencia estructural para el cese del mal en este mundo no es que la filosofía procure a la ciudad un conjunto de recetas, de mathématas, de normas de acción para la esfera de lo político, sino que el sujeto político sea también el sujeto de la filosofía y, con ello también, de una percepción crítica de lo que hay. Se trata, pues -insistimos en ello-, de la cuestión de un sólo y mismo sujeto como «punto de intersección entre "gobernar como es debido" y "practicar la filosofia"». "Punto de intersección" no de identificación ${ }^{94}$.

Coincidencia, pues, entre sujetos, pero también coincidencia en un mismo sujeto, aquel que es político y practicante de la filosofía, de una relación -con la diferencia que esta supone- que se actualiza en el ejercicio del pensar: la relación de uno consigo mismo. Por la filosofía uno llega a ser dos -actualiza su diferencia-y, sólo así, llega a ser un sujeto de decisión y acción.

Sería preciso, sin embargo, no perder de vista que la práctica filosófica, como actividad crítica en relación a la política, requiere, para ser efectivamente tal, de una dimensión pública que, en su lectura foucaultiana, no parece estar presente en la Carta VII de Platón, sino en lo que el pensador francés llama el «eclecticismo kantiano» 95 de la Beantwortung. Y es que, en Platón, el lugar en que se establecía la «correlación no coincidente» de la práctica política y de la filosofía no era la plaza pública, sino el sujeto de la soberanía, y, justamente, para que él fuera sujeto de tal soberanía. El lugar era entonces el sujeto político o, como dice Foucault, el «alma del príncipe»96, en ningún caso la ciudad. Siendo así las cosas el filósofo será el que, atendiendo al reclamo del poder político, habla al soberano, al sujeto de la soberanía, y le dice una verdad crítica que ha de procurar efectos de subjetivación sobre la práctica política. Ahora bien, esa palabra, para ser efectivamente palabra crítica, debería de ejercerse bajo condiciones de publicidad y no en la soledad de las estancias del príncipe, tal como se deja percibir en la lectura foucaultiana de la carta VII. Un tal ejercicio público del pensamiento exigiría lo que puede llamarse la irrupción de Sócrates en el pensamiento de la Carta VII de Platón, como garantía de que la palabra de la filosofía no será manipulación, ni palabra privada, sino el hablar mismo del logos, de todos y de nadie a un tiempo. Platón y Diógenes, un socrático que es hombre del ágora, podrían así cruzarse y complementarse en una nueva figura de la relación filosofía y política, que encontraremos mucho después, justamente en el eclecticismo de Kant ya señalado, en el que el propio Foucault, tal

\footnotetext{
93 Ibidem, p. 272.

94 Idem.

95 Ibid., p. 270

96 Ibid., p. 269.
} 
como ya hemos señalado, se reconoce. Y es que en Kant armonizan dos maneras de entender la relación filosofía y política que se oponen tradicionalmente: «Platón y Diógenes se oponen» ${ }^{97}$, dice Foucault. De un lado, Platón, para el que el alma del príncipe, el sujeto político, es el lugar de ese encuentro entre la filosofía y la política: por el trabajo de la filosofía, aislada de una relación con los otros que se considera fuente de opinión, se trata de producir una voluntad política, un sujeto político. Pero, de otro lado, está Diógenes, que coloca la filosofía frente a esa voluntad en un enfrentamiento desafiante e irrisorio que la inquieta y pone en cuestión, bajo el presupuesto de que la práctica política, toda forma de práctica política, nos hace esclavos. Y para Diógenes este encuentro -siempre belicoso- se producirá en un lugar de confrontación con el sujeto de la soberanía, con el sujeto político: el ágora, la plaza pública, como espacio no político en el que ha de surgir públicamente la verdad crítica que se opondrá a toda forma de organización política. La oposición en juego se produce entonces entre la idea de un espacio filosófico y público, pero no político, sino en confrontación con la práctica política (el ágora de Diógenes) y la idea de un espacio filosófico y político pero enteramente privado (el alma del príncipe en Platón).

En el marco general de esta oposición, en Platón, la obediencia al soberano nunca será puesta en cuestión y ella se fundará en el juego crítico de la filosofía y la política que se libra en él, un juego que, con independencia de toda condición pública, ha de producir justicia. Para Diógenes, sin embargo, la filosofía ha de enfrentarse a la política y nunca ha de obedecer a su llamado, pues ella nos hace esclavos. Se ha de vivir, pues, al margen de la política y en permanente confrontación con ella, ganando así un espacio no político de libertad y comunidad.

Pues bien, Kant, como Platón, considerará que hay que obedecer, y que la filosofía, lejos de oponerse al poder político en un enfrentamiento desafiante, ha de contribuir a su formación, a la formación de un sujeto político. Pero, como Diógenes, considerará que la libertad crítica sólo se alcanza en la apertura de un espacio público. De ahí que la obediencia al poder esté supeditada, en Kant, a la condición de la existencia de tal espacio público, como única garantía de que la libertad de la crítica podrá efectivamente tener lugar y, con ello, el ejercicio del poder político bajo condiciones de la «más amplia libertad»98. Cuando se dan estas condiciones de publicidad crítica y el poder, en tanto poder ilustrado, se pliega a las exigencias de la misma, se debe obedecer, incluso cuando uno no está de acuerdo con la ley, pues siempre existirán procedimientos de modificación pública y política de las leyes. Ahora bien, se debe obedecer sólo bajo estas condiciones. Citamos el texto en el que Foucault aborda este punto:

97 Ibid., p. 270

98 Kant, I. KrV, A316/B373. 
(...) a lo largo de la historia del pensamiento occidental vamos a reencontrar estas dos polaridades ¿El discurso de la filosofía debe ser el que se dirige al alma del príncipe para formarla? ¿O el discurso verdadero de la filosofía debe tener lugar en la plaza pública, como desafío, enfrentamiento, irrisión y crítica por relación a la acción del príncipe y a la acción política? Si recuerdan es, en el fondo, lo que habíamos visto en ese texto sobre la Aufklärung con el cual habíamos comenzado el curso de este año. En su teoría de la Aufklärung, Kant intenta mantener las dos cosas a la vez. El intenta explicar cómo el decir verdadero filosófico tiene simultáneamente dos lugares, que son no solamente compatibles, sino que apelan el uno al otro: de una parte el decir verdadero tiene lugar en lo público; el decir verdadero tiene también su lugar en el alma del príncipe, si el príncipe es un príncipe ilustrado. Tenemos ahí, si ustedes quieren, una especie de eclecticismo kantiano, que intenta mantener unido lo que ha sido tradicionalmente (...) el gran problema de las relaciones filosofía y política en Occidente: ¿será en la plaza pública o en el alma del príncipe?99

Foucault hace notar así la importancia decisiva de la Beanwortung para la comprensión del problema de la relación filosofía y política, en ella tendría lugar «una cierta manera, para la filosofía, de tomar conciencia, a través de la crítica de la Aufklärung, de problemas que eran tradicionalmente en la Antigüedad aquellos de la parresía»100. Así, si en los desarrollos del curso del 83 el texto platónico se presentaba como el lugar en que la cuestión de la parresia encontraba su definición fuera del contexto político de la democracia -en franca decadencia en tiempos de Platón-, como «el problema de la acción filosófica propiamente dicha»101 (no como el problema de la acción política, sino como el problema de la acción filosófica sobre la política, como única manera de arrancarse de la injusticia de este mundo) la Beantwortung se revelará como el espacio de emergencia de un modo moderno de hacer filosofía que reactiva el problema del dire-vrai como el asunto de una actividad propiamente filosófica, como problema de la actualidad de la filosofía, habilitando una concepción de la historia y de la política esencialmente vinculadas a la filosofía y considerando a ésta «en lo que se podría llamar su fuerza ilocutoria» 102.

Pero la consideración de esta fuerza ilocutoria, de esta realidad o actualidad, poco tiene que ver con una interpretación del enunciado filosófico como una realidad performativa. Antes bien Foucault establecerá el enunciado performativo como «contraejemplo» del enunciado parresiástico ${ }^{103}$ y filosófico. Se definen así las condiciones de lo que puede llamarse una «dramática del discurso». Así, si la pragmática es el «análisis de los elementos y de los mecanismos por los cuales la situación

\footnotetext{
99 Foucault, M., op. cit., p. 270.

100 Ibidem, p. 322.

101 Ibid. p. 190.

102 Ibid., p. 322.

103 Ibid., p. 59.
} 
en la que se encuentra el enunciante va a modificar lo que puede ser el valor y el sentido del enunciado»104 la «"dramática” del discurso consistirá «en el análisis de los hechos de discurso que muestra cómo el acontecimiento mismo de enunciación puede afectar al ser del enunciante» ${ }^{105}$. No situación, entonces, sino acontecimiento discursivo-filosófico que rompe con la situación dada y es libertad. Se trata entonces de la articulación del dire vrai, no con el conocimiento, sino con el sujeto de acción, y, por tanto, con la libertad: «vemos en todo caso que la parresía pone en juego una cuestión filosófica fundamental, que no es ni más ni menos que la de la del lazo que se establece entre la libertad y la verdad»106. En suma, lo que la dramática del discurso vendría a analizar es el acontecimiento mismo de la enunciación filosófica como práctica de la verdad, un cierto initium, el de un pensar por sí mismo, el de un pensar de acuerdo consigo mismo y el de un pensar en el lugar de cualquier otro ${ }^{107}$, el propio de lo que puede llamarse un sujeto de sensus communis 108 , aquel que siente lo intolerable.

\section{El principio de todos los principios de la historia del pensamiento o de la comunidad humana}

Lo que, entonces, el dire-vrai, como discurso y práctica de la filosofía, pone en juego es el lazo de la verdad con algo otro, que ha de operar como principio de la obligación por la verdad. Tal principio no es sino la libertad, como decisión y acción, y no como "naturaleza". Y es que el «objetivo es: la creación de libertad»109, en un trabajo de «ontología crítica» que se concibe como «una prueba históricopráctica de los límites que podemos franquear, y por tanto como trabajo de nosotros mismos sobre nosotros mismos en tanto que seres libres»110. Con ello se «busca relanzar tan lejos y tan ampliamente como sea posible el trabajo indefinido de la libertad»111, no el conocimiento.

Pero aun teniendo en cuenta la matización señalada, tal afirmación sobre la existencia de un principio que obliga a la crítica parece contradecir un sin número

\footnotetext{
104 Ibid. p. 65.

105 Ibid., p. 66.

106 Ibid., p. 64.

107 Ibid., pp.60 y ss.

108 Kant, I, Kritik der Urteilskraft, S-40, Stuttgart, Reclam, 2006, pp. 213-218. Sobre este asunto $c f r$. Díaz Marsá, M., "Ilustración y decisión. Consideraciones en torno al enunciado 'Yo percibo lo intolerable"”, Madrid, Escolar y Mayo ed. (en prensa).

109 Notas manuscritas de Foucault, cit. por Morey, M. en "Introducción” a Foucault, M., Tecnologías del yo, Barcelona, Paidós, 1991, p. 24.

110 Foucault, M., “Qu' est-ce que les Lumières?” en DE, IV, op. cit., p. 575.

111 Ibidem p. 574.
} 
de declaraciones de Foucault, en las que éste reconoce abiertamente y sin ninguna ambigüedad su nominalismo. La cifra de dos lugares en el dispositivo textual "Foucault" puede servirnos como muestra de tal «elección de método»112Así, en la primera versión al Préface à l'Histoire de la sexualité II Foucault se referirá a la necesidad de operar, junto al desplazamiento por relación al dominio, los conceptos y métodos de la historia de las sociedades, «una reducción "nominalista" de la antropología filosófica»113, si lo que se pretende estudiar las «formas de la experiencia» en su historicidad propia. Por otra parte, en Naissance de la biopolique Foucault hará mención a su «modo de proceder», consistiendo éste no en arrancar de ciertos universales y, a partir de ellos, deducir una serie de fenómenos concretos, o en tomar estos universales como clave de inteligibilidad de las prácticas históricas, sino en "comenzar" por las prácticas, tal como se presentan, para pasar luego los universales por su clave de inteligibilidad histórica. Se trataría así de ver cómo esos universales pueden constituirse en los hechos, en entramados prácticos 114

Otros textos, sin embargo, dan a pensar otras posibilidades, y ello hasta el punto que especialistas como Fimiani o Dreyfus y Rabinow han llegado a reconocer «una dimensión normativa» en el pensamiento de Foucault («no lejana, en este contexto, a las instancias del universalismo y de formalismo en la razón práctica kantiana») que no se vería comprometida por la «ausencia de una teoría o un sistema normativo» en dicho pensamiento115. A nuestro juicio, tanto las prácticas discursivas como las intervenciones políticas pertenecientes al último periodo del pensamiento foucaultiano habilitan una reconsideración de la cuestión del principio, acorde con la articulación coherente de lo que se considera la realidad o la efectividad de la libertad y de la crítica en este mismo periodo. Así, un texto como Qu-est-ce que la critique? Critique et Aufklärung establecerá en su comienzo el "haber" (no digamos el existir) de un principio de unidad y de autonomía de la crítica, que operaría como su «imperativo más general», «más general incluso que aquel de descartar los errores», más general, pues, que la verdad en su «función de utilidad» para con los diversos saberes. Y es que «hay algo en la crítica -señala Foucault- que tiene parentesco con la virtud». El principio, pues, no lo será para la productividad de los sabe-

112 La Naissance de la biopolitique. Cours au Collège de France. 1978-1979, Paris, Gallimard/Seuil, 2004, p. 4.

113 “Préface à....(première rédaction)" en DE, IV, p.579.

114 La Naissance de la biopolitique..., op. cit., pp. 4-5.

115 Fimiani, M., Foucault y Kant. Crítica, clínica, Ética, Buenos Aires, Herramienta ed., 2005, p, 11; cfr. También Dreyfus, H, Rabinow, P., Habermas et Foucault. Qu'est-ce l'agê d'homme, num. 471472. Asimismo Pablo López Álvarez en "La guerra infinita, el enigma de la sublevación. Michel Foucault y la interpretación bélica de la política" ha señalado: «la potencia de la sublevación puede confluir con el espacio normativo en el campo general de la lucha contra un poder infinito, al que hay que «oponer siempre leyes infranqueables y derechos sin restricciones». En La guerra, ed. de Nicolás Sánchez Durás, Valencia, Pre-textos, 2006. 
res, habiendo de marcar, más bien, su telos moral, el que hace de una vida unidad y libertad. Siendo así las cosas, la crítica no podrá resolverse en el modo de una pura operación mental, y se considerará más bien una forma de vida buena, un ethos. Con ello se trata de «la actitud crítica como virtud en general» 116 .

Pero tal principio no lo es sólo de la crítica y opera también en el dispositivo foucaultiano de la última época como el fundamento de una verdadera política, que nace y crece desde la peculiar comparecencia de dicho principio. "Peculiar" desde el momento en que ella se da -no puede ser de otra manera-bajo condiciones de finitud, las que establecen la necesidad de lo que puede llamarse, con André Glücksmann, una «evidencia negativa»117. Pues bien, tal punto de anclaje para la posibilidad del sentimiento de lo insoportable, para esa percepción de lo intolerable que desencadena pronunciamientos y acciones comunes se nombra en Face aux gouvenements, les droits de l'homme como «personne», como nadie 118 «¿Quién nos ha convocado?»-se pregunta Foucault en ese texto-. Nadie. Y es esto justamente lo que nos da nuestro derecho». Y unas líneas más adelante el francés señalará que «existe una ciudadanía internacional que tiene sus derechos, que tiene sus deberes y que compromete a levantarse contra todo abuso de poder». Una ciudadanía, pues, formal o sin peculiaridades de contenido, vacía, -la ciudadanía no nacional, sino internacional de nadie- que ha de fundar una política general de «los derechos del hombre» en tanto que tal -no en tanto que francés o español, católico o musulmán, etc.-, frente a los abusos gubernamentales. Los derechos del hombre funcionarían así como una barrera irrebasable por relación a cualquier abuso de poder, como «los límites que se plantean para todos los gobiernos posibles», sin poder, en ningún caso, violentar tales límites y constituyendo «la estructura y el cuadro mismo de su acción política» ${ }^{119}$ :

Si los gobiernos hacen de los derechos del hombre la estructura y el cuadro mismo de su acción política, tanto mejor. Pero los derechos del hombre son sobre todo lo que se opone a los gobiernos. Ellos son los límites que se plantean para todos los gobiernos posibles 120 .

Se pone, pues, ahora en juego el punto de anclaje de «todos los derechos»121 y de una lucha por la libertad -no sólo reclamada, sino también adquirida en la his-

\footnotetext{
116 Foucault, M., "Qu'est-ce que la critique? Critique et Aufklärung”. en Bulletin de la société française de philosophie., 84 année, na 2, p. 36.

117 Glücksmann, A. "El nihilismo de Michel Foucault" en VV. AA., Michel Foucault, filósofo Barcelona, Gedisa, 1990, pp. 332-333.

118 Foucault, M., "Face aux gouvernemens...", en $D E$, IV, p. 707.

119 "Michel Foucault: L'expérience morale et sociale des Polonais ne peut plus être effacée" en $D E$,

IV, p. 349.

120 Ibidem.

121 “Inutile de se soulever?" en DE, III, p. 791.
} 
toria-que no podrá ser, según venimos viendo, sino la libertad de cualquier hombre, cualquiera sea su singularidad, que habrá de ser siempre respetada según la prescripción de lo que Foucault presenta en Inutile de se soulever? como una «moral antiestratégica»: «ser respetuoso cuando una singularidad se subleva, intransigente cuando el poder infringe lo universal» ${ }^{122}$. Punto de anclaje que opera y funda derecho en la historia en la inmediatez de una experiencia conflictiva, no a través de teoría filosófica alguna sobre la naturaleza humana. En este sentido, se ha hecho notar que Foucault en sus últimos pronunciamientos e intervenciones sitúa al fondo de la limitación jurídica del poder un combate, una lucha política, y no una «fundamentación teórica basada en el reconocimiento de realidades esenciales y derechos naturales» ${ }^{123}$ : en la inmediatez de las luchas y al través del sentimiento de lo intolerable comparece el principio de toda acción y se establece en la historia el límite de todo ejercicio gubernamental. En relación a esto último conviene recordar que lo intolerable sólo puede experimentarse ahi donde hay efectivos límites infranqueables ${ }^{124}$, algo así como constitución interna de la materia, justamente la propia de esa materia cualificada (o condición ontológica) que es la libertad. De ahí que la producción por relación a esta libertad no pueda ser ilimitada y ante el poder de hacer de sí mismo se erija el límite de un deber, de acuerdo con las exigencias de una antropología pragmática de corte kantiano, tal como la foucaultiana. Una antropología que no ha de tratar de lo que es el hombre, sino de lo que el hombre, en tanto ser libre en el mundo, puede y debe hacer de sí mismo125.

Para terminar este apartado quisiéramos insistir en el problema de la comparecencia sui generis de este principio. Foucault se pregunta con qué derecho el intelectual puede ejercer un poder pastoral, prescribir conductas o establecer programas ${ }^{126}$. Tal posibilidad habría de estar fundada en la captación positiva de un principio de la acción, solidaria de lo que puede llamarse un «humanismo positivo», un

\footnotetext{
122 Ibid., p. 794.
}

123 López Álvarez, P., "La guerra infinita, el enigma de la sublevación. Foucault y la interpretación bélica de la política”, en La guerra, ed. cit., p. 20.

124 Sería preciso entonces distinguir en Foucault aquellos límites que pueden franquearse de aquellos otros, irrebasables, en nombre de los cuales tal franqueamiento de los límites históricos se impone como un deber, $c f r$. "Préface à la transgression" donde Foucault establece una diferencia, marcada ortográficamente, entre la Limite y la limite, en DE, I, pp. 233-250.

125 Kant, I., "Anthropologie in pragmatischer hinsicht" en Schriften zur Anthropologie, Geschitchts.phiposophie, Politik und Pädagogik. Werkausgabe Band XII, Framkfurt am Main, Suhrkamp, 1977, p. 399. Sobre este asunto cfr. Foucault, M., Introduccion à l'Antropologie, Paris, Vrin, 2008 pp. 32-33 y Davila, J., Gros, F. Michel Foucault, lector de Kant, Merida, Universidad de los Andes ed., 1998. Asimismo Díaz Marsá, M.,Modificacaciones. Crítica, Antropología y política en el pensamiento de Foucault, Madrid, Escolar y Mayo ed., 2014, y Sardihna, D., "Différence entre l'anthropologie pragmatique et l'anthropologie métaphysique" en Rue Descartes, monográfica sobre L'homme après sa mort, Kant après Foucault, no 75, 2012/13, pp. 46-59.

126 "Le souci de la vérité" en $D E$, IV, p. 676. 
humanismo muy preciso, aquel del siglo XIX y XX, «que daba al hombre europeo un saber respecto de los valores supremos» ${ }^{127}$. Pues bien, tal saber, por principio sólo al alcance de hombres excepcionales o divinos, habría conducido la ceguera del colonialismo, el fascismo o los campos siberianos. Foucault nos previene sobre sus peligros y se desmarca muy nítidamente de la posibilidad de una tal concepción del saber (como saber infinito) de los principios, proponiendo aquella otra en que se trataría de «elaborar empeños, compromisos, morales, no partiendo de una idea positiva del bien con valor universal y eterno, sino partiendo de una percepción, de una evidencia index sui de lo intolerable $\gg 128$. De acuerdo con esta consideración, el principio de la crítica y la política que opera en el pensamiento del último Foucault comparecería, ciertamente, en el saber, pero siempre indirectamente, de manera negativa y a través de la experiencia positiva de un sentimiento de dolor intolerable, que hace comunidad y desencadena acciones y pronunciamientos verdaderamente políticos. "Yo percibo lo intolerable", decía Foucault, y en tal percepción anclaba éste prácticas discursivas y no discursivas con vocación universal. Y es que lo que así comparece e impulsa la teoría y la práctica foucaultiana no es otra cosa que la comunidad humana, la humanidad, Menschheit, en la superación de toda configuración antropológica-fundamental del sujeto y como solapamiento de lo público, lo universal y lo libre en el ejercicio de la razón ${ }^{129}$.

\section{A modo de conclusión}

Como hemos dicho, la primera versión del prefacio a la Histoire de la sexualité II es uno de tantos textos de Foucault en los que considera necesario mirar su trabajo en retrospectiva. También hemos señalado que no aparece allí aún la noción de problematización. Pero es claro que esta noción estaba ya madurando en su pensamiento. De hecho, un importante cambio que hay entre las dos versiones del prefacio es que todo lo expresado en la primera se condensa en torno a esa noción en la segunda. Y es la segunda versión el texto en el que se conceptualiza la noción de problematización para dar cuenta del trabajo en retrospectiva (Modifications). Podemos decir, pues, que el primer prefacio es la antesala de la aparición de ese importante concepto clave en los últimos textos e intervenciones de Foucault.

$\mathrm{Al}$ decir que es un concepto clave queremos significar que con él Foucault es capaz de enlazar todo el problema de su trabajo sobre la historia del pensamiento y de sus principios. En este triple sentido que ya hemos mostrado: 1) problematiza-

127 Glücksmann, A., "El nihilismo de Foucault" en op. cit., 332.

128 Ibidem.

129 Foucault, M. “Qu, est-ce les Lumieres?” en DE, IV, pp. 565-566. 
ción del poder, de la política, que es también una política de las problematizaciones; 2) problematización del saber, del conocimiento, que es también una construcción de saber para las problematizaciones; 3) problematización de la ética, de lo que somos, que es también una ética de las problematizaciones. Pero, el concepto clave, permite también a Foucault hilvanar algo aún más refinado; ese algo que hemos indicado como índice de la finitud del pensamiento (ser) que reúne en su dominio o, mejor dicho, constituye el espacio propio de los tres ejes de la ontología foucaultiana. Como ya lo hemos sugerido, se trata de una suerte de segundo nivel de la problematización de la ética y, por ende, de la ética de las problematizaciones. Es en este segundo nivel, el de una Ética que otorga todo su sentido a toda la ontología foucaultiana, donde se plantea la cuestión de fondo que siempre inquietó el pensamiento de Foucault, la cuestión de la actitud del intelectual, o mejor del filósofo. Esta actitud del intelectual, del filósofo, no es separable de la actitud, del ethos, del modo de ser: es constitutiva de esa Ética. Y lo es, en la medida en que ella puede conducir toda la problematización de la(s) ética(s) -la crítica de la moral, la política de la intervención, el conocimiento histórico (arqueológico y genealógico) de los modos de ser- para conformar una ética de las historias de las problematizaciones en cuanto estas son el modo específico y concreto de la práctica del intelectual, del filósofo que es Foucault. A esa Ética, en su claridad conceptual, es conducido Foucault en sus últimos cursos con la noción de vida filosófica: «una verdadera vida de un tipo absolutamente otro que la vida de todos los días»; la vida del filósofo que incesantemente busca ser, busca ser «aquél que por el coraje de su direvrai, hace vibrar [brillar], a través de su vida y de su palabra, el relámpago de una alteridad» 130 .

\section{Referencias bibliográficas}

ARENDt, H., "El pensar y las reflexiones morales" en De la historia a la acción, Barcelona, Paidós, 1995.

DÁvila, J.,/Gros, F., Michel Foucault, lector de Kant, Mérida, Universidad de los Andes, 1998

Deleuze, G., Foucault, Barcelona, Paidós, 2007.

Dreyfus, H.,/Rabinow, P., "Habermas et Foucault" en Qu'est-ce l'agê d'homme, num. 471-472.

DíAz MARsÁ, M., Modificaciones. Ontología crítica y antropología política en el pensamiento de Foucault, Madrid, Escolar y Mayo, 2014.

${ }^{130}$ Le courage de la vérité,... op. cit., pp. 218 y 328. 
Díaz Marsá, M., “Arqueología de la cuestión trascendental” en Pensamiento. Revista de investigación e información filosófica, Universidad Pontificia de Comillas, vol. 67, num. 254.

DíAz MARsÁ, M., "Ilustración y decisión. Consideraciones en torno al enunciado «Yo percibo lo intolerable»" en Actas del congreso Respuesta a la pregunta ¿Qué es la Ilustración? 1784-2010, Madrid, Escolar y Mayo ed. (en prensa).

Fimiani, M., Foucault y Kant. Crítica, clínica, ética, Buenos Aires, Herramienta, 2005.

Foucault, M., Introduction à l'Anthropologie, Paris, Vrin, 2008.

Foucault, M., Les mots et les choses, Paris, Gallimard, 1999.

Foucault, M., L'archéologie du savoir, Paris, Gallimard, 1999.

Foucault, M., Dits et écrits. 1954-1988 (4 vol.), Paris, Gallimard, 1994.

Foucault, M., La Naissance de la biopolitique. Cours au Collège de France. 19781979, Paris, Gallimard/Seuil, 2004.

Foucault, M., Herméneutique du sujet. Cours au Collège de France. 1981-1982, Paris, Gallimard/Seuil, 2001.

Foucault, M., Le gouvernement de soi et des autres. Cours au Collège de France. 1982-1983, Paris, Gallimard/Seuil, 2008.

Foucault, M., Le courage de la vérité. Cours au Collège de France. 1984, Paris, Gallimard/Seuil, 2009.

Foucault, M., "Qu'est-ce que la critique? Critique et Aufklärung" en Bulletin de la société française de philosophie., 84 année, $\mathrm{n}^{\mathrm{a}} 2$ 2,.p36.

Gros, F., "Foucault. L'abus d'obéissance" en Libération, www. Liberation.fr/page.php? Article=216729.

GlÜCKSmann, A., "El nihilismo de Michel Foucault" en VV. AA., Michel Foucault, filósofo, Barcelona, Gedisa, 1990.

KanT, I., Kritik der Ursteilskraft, Stuttgart, Reclam, 2006.

KANT, I., "Anthropologie in pragmatischer Hinsicht" en Schriften zur Anthropologie, Geschitchtsphilosophie, Politik uns Pädagogik. Werkausgabe, Band XII, Framkfurt am Maim, Suhrkamp, 1977.

López Álvarez, P., "La Guerra infinita, el enigma de la sublevación. Michel Foucault y la interpretación bélica de la política" en La guerra, Valencia, Pretextos, 2006.

Morey, M., "Introducción” a Foucault, M., Tecnologías del yo, Barcelona, Paidós, 1991.

Potte-Bonneville, M., Michel Foucault, la inquietud de la historia, Buenos Aires, Manantial, 2007.

Platón, "Lettre VII" en CEuvres Complètes (Tome XIII, 1ère partie), Paris, Les Belles Lettres.

PlatÓN, "République" en Cuvres Complètes (Tomme VII-1ère partie), Paris, Les Belles Lettres. 
SARDIHNA, D., "Différence entre l'anthropologie pragmatique et l'anthropologie métaphysique" en Rue Descartes, monográfica sobre L' homme après sa mort, Kant après Foucault, no 75, 2012/13,pp. 46-59.

Marco Díaz Marsá

Universidad Complutense de Madrid mdimarsa@filos.ucm.es

Jorge Dávila Rojas

Universidad de los Andes, Venezuela joda@ula.ve 